\title{
A Construção de Identidades Muçulmanas: Um Enfoque Comparativo entre Duas Comunidades Paulistas*
}

\section{Cristina Maria de Castro}

Universidade Federal de Minas Gerais, Belo Horizonte, MG, Brasil. E-mail: cristinamcastro@ig.com.br.

\section{INTRODUÇÃO}

\begin{abstract}
A visão do Islã como uma religião essencialmente étnica seguida por imigrantes e seus descendentes, juntamente com o fato de não constituir uma religião proselitista em franca expansão no Brasil, explica a pequena quantidade de trabalhos acadêmicos destinada ao seu estudo no país. No campo da religiosidade nacional, o que impera são estudos sobre a religião majoritária, o catolicismo, e sobre casos que vêm apresentando um imenso crescimento, como certas igrejas neopentecostais, por exemplo. O estudo do Islã no Brasil, porém, constitui um tema de análise valioso por várias razões: não se trata de uma religião isolada, situada além do campo religioso brasileiro; ao contrário, pode não só ajudar a compreender as religiões majoritárias localmente, servindo de contraponto a elas, como bem lembra Montenegro (2000), mas também ajudar a compreender as disputas por clientela efetuadas no âmbito nacional, já que o Islã não se encontra neutro neste ponto. Por fim, também é importante salientar o fato de o Brasil abrigar uma das maiores comunidades islâmicas da América Latina, respon-
\end{abstract}

\footnotetext{
* Contei com o financiamento da Coordenação de Aperfeiçoamento de Pessoal de Nível Superior (Capes) para a realização do meu doutorado em Ciências Sociais, concluído em 2007 na Universidade Federal de São Carlos (UFSCar) sobre o qual este artigo se baseia. A Capes também me possibilitou a realização de um estágio de doutorado-sanduíche no International Institute for the Study of Islam in the Modern World, em Leiden, Holanda.
}

DADOS - Revista de Ciências Sociais, Rio de Janeiro, vol. 57, no 4, 2014, pp. 1043 a 1076. 
sável por produzir o material de divulgação da religião que é distribuído por toda a parte sul do continente. A importância atribuída aos estudos do Islã no mundo constitui outra razão para justificar este trabalho: o interesse internacional no fenômeno das comunidades muçulmanas fora do chamado "mundo islâmico" é algo que só faz crescer nos últimos anos.

É possível apontar produções referentes à época da chegada do Islã ao Brasil, o período da escravidão, responsável pela vinda dos escravos malês, como o estudo clássico de Reis (2003). Nas produções acadêmicas a respeito da imigração libanesa para o Brasil, os muçulmanos costumam ser apenas citados, não apresentados como objeto central, uma vez que os cristãos foram o elemento predominante neste processo imigratório (Truzzi, 1997). Osman (1998), porém, em sua dissertação sobre a história oral da imigração árabe para São Paulo, procurou equilibrar o número de fontes muçulmanas e cristãs, enquanto Gattaz (2001) buscou preencher esta lacuna desenvolvendo sua tese sobre a imigração libanesa para o Brasil com enfoque no período pós-1940, caracterizado pela vinda de um maior número de muçulmanos libaneses para o país. Osman (2007), continuou contribuindo para o estudo dos muçulmanos introduzindo, desta vez, o debate sobre o retorno dos imigrantes ao Líbano. As produções acadêmicas visando o estudo das comunidades muçulmanas contemporâneas têm enfocado, majoritariamente, a questão da construção de identidades. Montenegro (2000) pesquisou dois dilemas identitários presentes na comunidade sunita do Rio de Janeiro: ser arabista ou postular a islamização e definir-se como fundamentalista ou não. Ramos (2003) e Marques (2000) focaram a conversão ao Islã, processo que, ao fim, constitui um movimento de reelaboração da identidade. O primeiro autor privilegiou o estudo dos homens convertidos ao Islã em São Bernardo do Campo e a segunda, as mulheres convertidas em São Paulo. Ferreira (2001), tinha como foco central analisar as imagens fotográficas a partir de três estatutos: as imagens produzidas pelos muçulmanos do Brás/Pari; pela imprensa e as que ela mesma produziu neste período. Não teve, porém, a questão da identidade como foco principal. Em seu doutorado (2007), procurou responder à seguinte questão: "Qual o sentido de ser muçulmano?", mais uma vez amparada pelo debate da antropologia da performance e sem ter a questão identitária como cerne de seu trabalho, apesar de não ignorá-la.

Espinola (2005), desenvolveu uma análise do uso do véu pelas mulheres muçulmanas de Florianópolis, atentando para os significados cul- 
turais, religiosos e morais que envolvem tal prática. Chagas (2006) pesquisou a construção da identidade muçulmana sunita do Rio de Janeiro através da perspectiva das diferentes apropriações do conhecimento muçulmano e das consequentes posições de poder que os membros assumem nesta comunidade. A pesquisadora teve como orientador o antropólogo Paulo Hilu Pinto (2012), que desenvolveu, entre outros, estudos sobre ritual, etnicidade e identidades religiosas entre muçulmanos em Curitiba, São Paulo e Rio de Janeiro.

Vitória Peres de Oliveira e Cecília Mariz (2006) contribuíram para a compreensão da conversão ao Islã no Brasil. Guilhon (2006) desenvolveu um estudo etnocenológico sobre os derviches em sua tese de doutorado em artes cênicas. Porém, assim como Ferreira (2001; 2007), não teve como foco a questão da construção de identidades. Hamid (2007), por outro lado, reforça a ênfase dos pesquisadores brasileiros nesta questão. Em sua dissertação de mestrado em Antropologia, analisou a construção identitária de mulheres palestinas em Brasília.

Procurei contribuir para este campo de pesquisa analisando na minha tese de doutorado (2007) a construção de identidades muçulmanas em duas comunidades paulistas. A coleta de dados empíricos deu-se através da técnica da observação participante durante todo o ano de 2004, em Campinas, e no primeiro semestre de 2006, no Brás. No primeiro caso, participei das celebrações religiosas às sextas-feiras, dos almoços dominicais organizados mensalmente no Centro Islâmico e de encontros femininos aos sábados, para o aprendizado da língua árabe. Estes últimos ocorreram apenas no momento final da pesquisa, promovidos por imigrantes líbias presentes temporariamente no país para acompanhar seus maridos, pesquisadores ligados à Universidade Estadual de Campinas (Unicamp). No Brás, pude assistir às celebrações religiosas realizadas às sextas-feiras, assim como as aulas de árabe e religião aos sábados, durante todo o semestre em que realizei a pesquisa naquela localidade. Também participei de almoços esporádicos na mesquita e de eventos específicos, como uma passeata na praça da Sé em prol da paz no Líbano, em julho de 2006, e o "Primeiro Encontro da Mulher Muçulmana nas Américas", realizado em Itapecerica da Serra, entre os dias 9 e 10 de outubro de 2004. A passeata foi organizada por diversos atores sociais, entre eles lideranças e membros de mesquitas paulistas. Já o segundo evento foi organizado pelo Centro de Divulgação do Islã para a América Latina (Cdial Halal). Por fim, cito os almoços nas residências de famílias muçulmanas de ambas as comunidades como mais 
uma oportunidade que tive para aprofundar meu conhecimento sobre os adeptos da religião islâmica em São Paulo.

Voltando para a descrição dos meus objetivos de pesquisa, busquei apreender como se dá o processo de construção de identidades muçulmanas frente: 1) à negociação com a sociedade brasileira, caracterizada pela forte presença do catolicismo, do crescimento do protestantismo, da cultura basicamente ocidental, do estado secular, da dependência dos EUA e da tradição de acolher os imigrantes e absorvê-los em um processo de abrasileiramento; 2) ao impacto da globalização sobre este grupo minoritário, tanto no sentido de propagação de estereótipos negativos a respeito do Islã e seus fiéis como consequência da influência da mídia e academia orientalistas, quanto no sentido de fortalecimento dos vínculos da diáspora com o restante do mundo muçulmano, e; 3 ) às negociações internas entre árabes e convertidos e entre homens e mulheres pela definição do que é ser muçulmano e muçulmana no Brasil ${ }^{1}$. Por fim, o estudo comparativo de duas comunidades muçulmanas com perfis tão distintos quanto as comunidades sunitas de Campinas e do Brás me permitiram analisar até que ponto ocupações, etnias e distribuições espaciais diversas podem gerar práticas e discursos islâmicos diferenciados, à luz dos campos previamente delimitados.

Na primeira etapa deste artigo faço, portanto, uma rápida explanação da presença muçulmana no Brasil atendo-me a questões como composição étnico-cultural, perfil econômico e ocupacional, além do processo de institucionalização do Islã nas comunidades aqui enfocadas: a Liga da Juventude Islâmica Beneficente do Brasil e o Centro Islâmico de Campinas. O segundo tópico é destinado à apresentação do processo de construção da "identidade muçulmana" daquelas comunidades frente ao campo religioso brasileiro predominantemente católico, porém marcado pelo considerável crescimento do protestantismo pentecostal nos últimos anos. O próximo tema a ser abordado é o impacto da globalização na construção de identidades muçulmanas no contexto minoritário brasileiro. Neste tópico, procuro destacar como o perfil socioeconômico desenvolvido pelos muçulmanos no Brasil afeta não só a maneira como veem a religião, como também o papel que desempenharão tanto na sociedade hospedeira quanto na Ummah ${ }^{2}$. Por fim, abordo a negociação da identidade no interior das comunidades, através da análise de conflitos étnicos e de gênero pela definição do que é ser muçulmano e muçulmana no Brasil de hoje ${ }^{3}$. 


\section{MUÇULMANOS NO BRASIL: QUEM SÃO E COMO VIVEM?}

Algumas lideranças muçulmanas brasileiras alegam que o Islã está presente no país desde a época do descobrimento, numa possível estratégia visando criar um lugar na história da "fundação" deste país e legitimar sua presença, que seria tão antiga quanto a do Cristianismo no Brasil. De qualquer forma, foi a partir do tráfico negreiro que um número mais elevado de muçulmanos definitivamente começou a chegar ao país. Os malês, muçulmanos de origem iorubana, majoritariamente nagôs, são os mais conhecidos deles. Em 1835, organizaram uma revolta, baseada ideologicamente na religião islâmica, que tomou as ruas de Salvador por horas, repercutindo até no exterior. Alguns dos escravos participantes do levante foram extraditados, outros, condenados à prisão, às chibatadas, ou, ainda, à pena de morte (Reis, 2003). $\mathrm{O}$ Islã passou a ser visto como algo a ser temido e controlado e quase desapareceu do campo religioso brasileiro. Uma nova fase da presença islâmica no país foi inaugurada com a chegada dos imigrantes sírio-libaneses. Estes representam a grande maioria dos muçulmanos no Brasil atualmente. É necessário esclarecer, no entanto, que a imigração de indivíduos sírio-libaneses para o Brasil apresentou diversos momentos, sendo o início marcado pela chegada quase exclusiva de elementos cristãos (Truzzi, 1997).

O movimento imigratório em questão teve início em 1880, período em que a Grande Síria ${ }^{4}$ encontrava-se dominada pelo Império Otomano. Com a decadência do Império e a sucessiva soberania francesa, os muçulmanos passaram a sentir-se em desvantagem devido ao tratamento preferencial que os cristãos começaram a receber, engrossando as correntes de emigração do Líbano.

Ao contrário de italianos, portugueses, espanhóis e outros grupos europeus, sírio-libaneses não contaram com o sistema de imigração subsidiada por não encaixarem-se no padrão das políticas imigratórias que visavam o branqueamento da população e também porque não se interessavam em se empregar como colonos. A maior parte dos que aqui chegaram não possuía capital para investir. Desta forma, a mascateação tornou-se a principal saída ${ }^{5}$. Conforme amealhavam algum capital, procuravam abrir pequenas lojas e chamar amigos e parentes para trabalhar consigo, vendendo suas mercadorias por consignação e dando início a um processo de imigração em cadeia. 
Quando os libaneses chegaram ao Brasil, a urbanização estava começando, o que ajuda a explicar porque foram tão bem-sucedidos no setor comercial, muito mais do que nos EUA, por exemplo (Truzzi, 1997). Libaneses e sírios, nesta ordem, constituem os maiores grupos de muçulmanos no país. Os palestinos encontram-se em terceiro lugar e vieram fundamentalmente após a criação do Estado de Israel. Egípcios, marroquinos, sudaneses, nigerianos, sul-africanos e moçambicanos representam outras nacionalidades de imigrantes que aqui se estabeleceram, em número expressivamente mais reduzido. Não há dados confiáveis sobre o número de muçulmanos no Brasil. Enquanto entidades nativas, como a Sociedade Beneficente Muçulmana de São Paulo, apontam uma quantia de cerca de um milhão de fiéis, o último censo indicou pouco mais de 27 mil muçulmanos no país. Acredito que seria necessário relativizar ambos os dados, primeiro, porque os muçulmanos costumam ser agrupados na categoria religiosa "outros" no recenseamento, e segundo, porque há uma tendência dos grupos religiosos de mostrarem-se maiores do que realmente são...

Os muçulmanos no Brasil concentram-se fundamentalmente nos estados de São Paulo, Paraná e Rio Grande do Sul. Apresentam nível educacional e rendimento bastante acima da média da população brasileira, atuando, em sua maioria, no setor terciário. Quase $40 \%$ dos muçulmanos são empregadores, contra apenas $4,3 \%$ da população urbana. Consequentemente, há uma reduzida participação de empregados no setor privado, $23,5 \%$, contra $48,1 \%$, enquanto a proporção de trabalhadores autônomos se aproxima, 28,5\%, contra 20\%. Desta forma, é possível afirmar que "o perfil majoritário do muçulmano ativo é o de um comerciante independente ou patrão de uma empresa que emprega menos de 10 pessoas. Porém, além deste arquétipo, o recenseamento de 1991 revela uma multiplicidade de situações" (Waniez e Brustlein, 2001:163).

\section{A LIGA DA JUVENTUDE ISLÂMICA BENEFICENTE DO BRASIL}

A mesquita da Liga da Juventude Islâmica situa-se na divisa entre os bairros do Brás e do Pari, na cidade de São Paulo, maior hospedeira de muçulmanos do Brasil. Foi fundada para atender à necessidade de um local de orações para os comerciantes de imigração recente que lá se estabeleceram. Cerca de 200 famílias compõem a comunidade, sendo a maioria delas oriunda da cidade libanesa de Trípoli. 
Os imigrantes muçulmanos da Liga seguiram os passos dos patrícios pioneiros, dedicando-se ao comércio em um sistema de cooperação mútua onde os mais antigos oferecem ajuda aos mais recentes, seja no ensino do idioma, no fornecimento de mercadoria em consignação ou no emprego. A região de origem encaminhou os muçulmanos para bairros ou cidades específicas no Brasil, e a socialização oferecida aos recém-chegados fez com que se concentrassem em um mesmo ramo de atuação. Desta forma, os imigrantes muçulmanos da Liga da Juventude concentraram-se no comércio de jeans, assim como os assentados na cidade de São Bernardo do Campo, por exemplo, se concentraram no comércio de móveis.

O processo de institucionalização do Islã presente naquela comunidade foi possível, em sua maior parte, graças à colaboração dos seus próprios membros. Em 1998, fizeram um projeto de construção de uma mesquita e procuraram ajuda financeira entre "os árabes que estavam bem de vida no Brasil" e em países árabes. Segundo um de seus fundadores, o dinheiro do exterior demorou tanto a chegar que foi usado para a compra de "carpetes e o elevador, o qual não fazia parte do projeto original, mas com a chegada do dinheiro resolvemos colocar". "O dinheiro chegou só no final, quando praticamente tudo já estava pronto", ressaltou ele, em uma clara tentativa de enfatizar a independência financeira da comunidade em relação ao restante do mundo muçulmano. A mesquita encontra-se em um prédio de três andares construído depois de seis anos de arrecadação entre os membros da comunidade. Trata-se de um grande imóvel com ótima infraestrutura para atender às atividades a que se propõe: um local de orações, de confraternizações e de ensino da religião islâmica e da língua árabe. Com perfil explicitamente proselitista, a mesquita oferece aulas e eventos destinados não apenas aos imigrantes e seus descendentes como também aos brasileiros das redondezas. Aulas de religião e língua árabe são oferecidas a crianças, cônjuges brasileiros e curiosos em geral. Inclusive, aparelhos de tradução simultânea foram comprados para permitir aos brasileiros a compreensão dos sermões de sexta-feira em sua íntegra.

Arábia Saudita, Kuwait e Emirados Árabes Unidos cooperaram de alguma forma com a construção desta e de outras mesquitas no Brasil. Estes países, juntamente com o Egito, seriam os principais colaboradores internacionais do processo de institucionalização do Islã no contexto local. Além da ajuda financeira para a construção de mesquitas, 
financiam sheikhs para dar aula de árabe e religião no Brasil e fornecem educação religiosa para líderes muçulmanos locais naqueles países.

\section{O CENTRO ISLÂMICO DE CAMPINAS}

O Centro Islâmico de Campinas foi fundado em 1977, graças à iniciativa de seu hoje presidente, Ismail Hatia. Sul-africano de origem indiana, chegou ao Brasil em 1956 fugindo do apartheid, estabelecendo-se como empresário do ramo de ensino de idiomas no ano de 1960. Partiu para a África do Sul na década de 1970 com o intuito de levantar capital para a implantação do Centro Islâmico, e conseguiu arrecadar 25 mil dólares entre os membros da comunidade islâmica de origem indiana daquele país, a comunidade muçulmana indiana mais influente fora da Índia, segundo ele. Com o dinheiro, comprou um grande terreno no Parque São Quirino e deu início à construção da Mesquita, que pôde contar, posteriormente, com a ajuda de muçulmanos residentes na cidade de Campinas e região (Sorocaba, Piracicaba, Sumaré, Pedreira, Americana e Hortolândia), entre eles, pessoas de nacionalidade libanesa, sul-africana, indiana, palestina, egípcia etc.

A comunidade muçulmana de Campinas constitui uma exceção, entre outros motivos, pela maior heterogeneidade com relação aos demais centros islâmicos paulistas. Tal fato explica-se pela presença da Unicamp, segundo Mohamed Habib, líder da comunidade da região campineira. Egípcios deixaram seu país devido à perseguição política do ditador Nasser, alguns se tornando professores da Universidade Estadual de Campinas (Unicamp), como o próprio Habib, hoje Pró-Reitor de Assuntos Comunitários e Extensão. Os poucos líbios que foram para Campinas o fizeram basicamente em virtude de cursos de pós-graduação ou para exercer uma função docente, também naquela instituição de ensino. Outros grupos, como os sul-africanos de origem indiana gujarati estão presentes. Estes deixaram seu país fugindo do apartheid e aqui se estabeleceram trabalhando como empresários, fundamentalmente no setor de ensino do idioma inglês. Moçambicanos de origem indiana gujarati já chegaram a constituir maioria naquela comunidade, porém, decepcionados com as crises econômicas brasileiras desistiram do sonho de "fazer a América" e deixaram o país, em sua quase totalidade, na época do governo Sarney. Por fim, resta citar que em número muito pequeno ainda encontram-se, dentre aquele grupo, pessoas provenientes da Malásia e das Guianas. 
A heterogeneidade étnica presente em Campinas coloca o ideal da Ummah em destaque, uma vez que se torna fator quase que exclusivo de formação de uma identidade coletiva para os membros daquele grupo que, ao contrário dos muçulmanos do Brás, vivem dispersos pela cidade e trabalham relativamente independentes uns dos outros.

\section{A CONSTRUÇÃO DE IDENTIDADES MUÇULMANAS FRENTE AO CAMPO RELIGIOSO BRASILEIRO}

Durante minha pesquisa de campo, pude constatar relações do Islã com o catolicismo, religião majoritária, e com o pentecostalismo, vertente religiosa que mais acentua as relações de oposição e concorrência (Brandão, 1988). Como lembra Edward Said (1981), a doutrina islâmica pode ser vista justificando tanto a tolerância religiosa quanto $o$ exclusivismo. A tolerância religiosa faz parte do discurso oficial encontrado tanto no Centro Islâmico de Campinas quanto na Liga da Juventude Islâmica, porém, nesta última, o Cristianismo assume um papel muito maior de fornecedor de características diacríticas da sociedade local para a comunidade imigrante.

O trecho de um sermão de sexta-feira realizado no Centro Islâmico de Campinas sobre a unicidade divina revela a preocupação em mostrar que o Islã e os muçulmanos são bem vistos pela Igreja Católica:

A Declaração "Nostra Aetate" sobre as relações da Igreja com as Religiões Não Cristãs - Vaticano, 1966, aprovada por 2.221 votos, mais de $96 \%$, define a religião islâmica como: quanto aos muçulmanos, a Igreja igualmente os vê com estima e carinho, porque adoram a um único Deus vivo e subsistente, misericordioso e onipotente, Criador do céu e da terra, que falou aos homens. A seus semelhantes preceitos esforçam-se por se submeter de toda a alma, como a Deus se submeteu Abraão a quem a crença muçulmana se refere com agrado. Não reconhecem Jesus como Deus: veneram-no, no entanto, como profeta. Honram Maria, sua Mãe virginal e até a invocam às vezes com devoção. Aguardam, além disso, o dia do Juízo, quando Deus há de retribuir a todos os homens ressuscitados. Como consequência, valorizam a vida moral e honram a Deus no mais alto grau pela oração, esmolas e jejum.

A tolerância do Islã, por sua vez, frente não só ao catolicismo como ao Cristianismo em geral e ao Judaísmo, ou seja, às religiões dos chamados "Povos do Livro" também é enfatizada em um sermão de Campinas: "Analisando o parentesco resultante do casamento do muçulma- 
no com uma judia ou uma cristã, percebemos que pela natureza humana isto gera o apoio e a cooperação entre os dois lados. Maravilhoso é o sentimento que nasce entre os filhos e seus tios paternos e maternos. Isto é a tolerância, o pré-requisito da paz".

A ideia de que é dever do muçulmano crer nas religiões reveladas previamente (Cristianismo e Judaísmo) e em seus profetas faz parte do discurso oficial da Liga da Juventude Islâmica, presente nos sermões de sexta-feira, nas aulas de religião ministradas aos sábados e no website da Liga: "O Islamismo reconhece todas as religiões anteriores, Cristianismo, Judaísmo e (o muçulmano) tem que reconhecer todos da cadeia dos profetas. São irmãos de uma fonte só, uma mensagem só" ${ }^{\prime \prime}$.

O respeito não apenas ao "profeta Jesus" como à Virgem Maria (mulher mais citada no Alcorão, segundo o sheikh) é bastante salientado. Porém, as diferenças entre as religiões são muito demarcadas, a começar pela "confiabilidade" dos livros sagrados de ambas as religiões. Em um sermão, foi dito que a Bíblia teria sido escrita 300 anos após a morte de Cristo, ao contrário do Alcorão, que teria sido escrito enquanto o profeta Muhammad e seus amigos ainda estavam vivos. Tal argumento é utilizado para justificar a presença de erros na doutrina cristã. A veracidade da mensagem de Cristo não é negada, tampouco a origem divina dos seus ensinamentos, mas põe-se em questão o registro de sua mensagem, o qual teria sido responsável por diversos equívocos na transmissão da doutrina de Jesus.

Os muçulmanos se definem na Liga como tolerantes por reconhecerem as demais religiões, em contraposição aos judeus, "que não reconhecem Cristo", e aos cristãos, "que não reconhecem o profeta Muhammad", nas palavras do professor da turma iniciante daquela instituição. "O Islamismo não veio para anular as outras religiões, veio para corrigi-las", completou o professor.

Foi possível constatar que as lideranças de ambas as mesquitas direcionam seu diálogo fundamentalmente ao Cristianismo católico, detentor do maior capital simbólico dentro do campo religioso brasileiro. Por outro lado, foi possível notar uma forte presença de pentecostais (fundamentalmente da Assembleia de Deus) nas aulas destinadas aos curiosos e convertidos, na Liga, aos sábados. Ainda que várias das pessoas convertidas tenham realmente feito parte desta e de outras igrejas pentecostais como a Igreja Universal do Reino de Deus antes de filiarem-se efetivamente ao Islã, é notório que certo número destes visi- 
tantes não parece ter a menor intenção de se converter. Apresentando-se como cristãos interessados no diálogo entre as religiões e na oportunidade de aprender a língua árabe de graça, sempre polemizam nas aulas de religião, fazendo perguntas em sintonia com a cobertura da mídia a respeito do Islã e dos muçulmanos, como por exemplo: “É verdade que quando um homem-bomba se mata ele vai para céu e ganha 72 noivas virgens? E as mulheres, o que ganham?".

Os árabes parecem não perceber segundas intenções por parte destas pessoas, mas convertidos percebem, talvez até por estarem mais acostumados com estratégias de evangelização, inclusive por experiências prévias com religiões pentecostais. Certos evangélicos podem estar frequentando as aulas visando a impedir novas conversões ao Islã ou, quem sabe, aproveitar aquela oportunidade como um treinamento para missões evangelizadoras no exterior, em países majoritariamente muçulmanos.

Casos de discriminação e ataques verbais realizados por evangélicos contra mulheres muçulmanas foram reportados à pesquisadora Vera Marques (2000), assim como a mim, durante minha pesquisa de campo. Segundo uma informante de 21 anos, convertida há dois, os muçulmanos são criticados por "não acreditarem em Jesus". "Mas isto é um engano", disse ela, "porque acreditamos em Jesus! Como profeta, não como filho de Deus". "Concluem que somos contra Jesus", afirmou outra moça, 35 anos, convertida há oito.

No Centro Islâmico de Campinas não foi visto nada parecido no período em que frequentei a mesquita, de janeiro de 2004 a janeiro de 2005. A ausência de pentecostais naquela instituição religiosa talvez possa ser explicada pela pequena visibilidade da comunidade muçulmana de Campinas, formada por um pequeno número de pessoas vivendo dispersas pela cidade, com sede em um bairro afastado do centro, com número muito baixo de convertidos, um percentual quase nulo de mulheres usando o véu na esfera pública e a falta de infraestrutura para atrair novos membros em maior quantidade, como estratégias de divulgação, aulas de religião ou grandes eventos. OCentro Islâmico de Campinas vem mantendo-se como um ponto de encontro para orações e socialização onde praticamente todos se conhecem de longa data.

Apenas uma vez pude presenciar uma menção direta das lideranças árabes aos evangélicos, e esta foi referente ao caso do "chute na santa" efetuado pelo bispo Von Helder, da Igreja Universal, na década de 
1990. Na aula inaugural de religião para iniciantes, realizada na Liga em fevereiro de 2006, o presidente da União Islâmica do Brasil e membro fundador da Liga da Juventude Islâmica citou o caso:

Pegar o Profeta de mais de um bilhão de pessoas e fazer charges não é errado? Isso é liberdade de expressão? O "padre" que chutou a santa fugiu do Brasil porque a polícia não podia protegê-lo. Eu não rezo para imagem, mas considero no mínimo uma baixaria o que fizeram com a santa. Pisar na bandeira do Brasil é ofender a todos os brasileiros, não é liberdade de expressão.

Utilizou a agressão ao símbolo católico, por um membro de outra religião, para sensibilizar os presentes quanto à gravidade da ofensa contra o Islã cometida por cartunistas dinamarqueses e para justificar a indignação dos muçulmanos. Mais do que isso, foi interessante o reconhecimento, por parte dele, da imagem da padroeira católica como símbolo deste país, reconhecimento da força do catolicismo no Brasil. No mesmo dia, porém, enfatizou: "Quando o Islã reinou no mundo, não roubou de ninguém. Inglaterra e França roubaram a África e o Oriente Médio. Não porque os árabes são nobres, mas porque o Islã proíbe que se faça isso. O Brasil é um país católico graças à tolerância do Islã, porque quando (os árabes) dominaram Portugal, deram liberdade de crença aos cristãos".

O perfil da comunidade da Liga da Juventude Islâmica, um grupo numericamente grande, concentrado no mesmo bairro, com alto capital econômico, composto por imigrantes recentes liderados por jovens, produz um discurso mais "combativo" e "demarcador de território" do que o encontrado em comunidades como a do Centro Islâmico de Campinas, um grupo pequeno, disperso, pouco visível, concentrado no setor educacional, com um capital econômico não tão alto e composto por imigrantes na faixa dos 60, 70 anos e seus descendentes. Enquanto a comunidade da Liga da Juventude procura apontar os erros presentes no Cristianismo e atribuir a predominância deste no Brasil graças à tolerância dos árabes no período de dominação da Península Ibérica, os líderes de Campinas preocupam-se em mostrar que o Islã e os muçulmanos são apreciados pela Igreja Católica, buscando aceitação por parte da sociedade hospedeira. O dinamismo dos jovens da Liga, aliado à sua maior fonte de recursos, é empregado no objetivo explícito de divulgar a palavra divina no país receptor, como nos mostra o trecho extraído de um discurso do diretor da Liga: "Os árabes conseguiram fazer com que em cada bar, em cada esquina, fossem vendidas 
esfirras, mas e a palavra de Deus? Não passou nem da primeira esquina. Falhamos nisso e esta deve ser a nossa contribuição aos brasileiros, levar a palavra de Deus até eles".

\section{GLOBALIZAÇÃO, REDES ISLÂMICAS TRANSNACIONAIS E SUA INFLUÊNCIA NA CONSTRUÇÃO DE IDENTIDADES MUÇULMANAS NO BRASIL}

O impacto da globalização no processo de construção identitária de imigrantes muçulmanos pode ser visto de diversas maneiras. O interesse das superpotências em terras majoritariamente muçulmanas, a questão Palestina, a reação de movimentos de resistência ao imperialismo ocidental apoiados em leituras da religião islâmica, assim como a vida das minorias muçulmanas na Europa e nos EUA são exemplos de fatores que afetam a forma como os muçulmanos no Brasil veem a religião e a si mesmos. Ao mesmo tempo que a globalização traz à tona o Anti-Muslimism ${ }^{7}$ difundido pela mídia ocidental, ela reafirma os laços da diáspora com os países de origem e o restante da comunidade muçulmana mundial. Neste aspecto, é importante frisar que o perfil socioeconômico privilegiado desenvolvido pelos muçulmanos no Brasil afeta não apenas a forma como veem sua própria religiosidade, como também o papel que desempenham tanto na sociedade hospedeira quanto na Ummah.

\section{Considerações sobre o "Fundamentalismo Islâmico" e seu Impacto no Brasil}

O Islã constitui a religião que mais vem crescendo no mundo, ao mesmo tempo em que assume o papel de alvo de um processo de "demonização" de toda uma religião e seu conjunto de fiéis. Este tópico é destinado ao esclarecimento da origem e do significado de um dos termos mais associados, pela mídia, aos muçulmanos atualmente, o fundamentalismo.

Segundo Armstrong, o termo fundamentalismo surgiu quando protestantes americanos no início do século $\mathrm{XX}$ passaram a denominar-se "fundamentalistas" para diferenciarem-se de outros protestantes mais liberais que distorceriam a fé cristã. Sua intenção era "voltar às raízes e ressaltar o fundamental da tradição cristã", isto é, "a interpretação literal das Escrituras e a aceitação de certas doutrinas básicas" (2001:10). 
A partir deste momento, a palavra fundamentalismo passou a ser usada para designar movimentos reformadores de outras religiões, gerando uma série de equívocos. Beinin e Stork (1997) alegam que não faz sentido falar em fundamentalismo islâmico, uma vez que, para seus fiéis, o Alcorão já é considerado a palavra literal de Deus, conforme revelada ao seu profeta Muhammad por intermédio do anjo Gabriel. Fundamentalismo também não é sinônimo de terrorismo ou apregoação da violência, como mostra a mídia.

A maioria dos fundamentalistas não concorda com atos terroristas, embora costume ser exclusivista e condenar quem não siga suas ideias (Armstrong, 2001). Da mesma forma, é necessário enfatizar que "a volta às escrituras" não representa uma exclusividade do Islã, e está presente em todas as religiões tradicionais. Os movimentos fundamentalistas seriam reações à cultura moderna, marcada por medos, ansiedades e desejos comuns. Para Karen Armstrong (2001), o fundamentalismo é uma reação à cultura científica e secular que nasceu no Ocidente e depois se espalhou pelo mundo. Ele rejeita o racionalismo científico, mas não tem como fugir dele. Geertz (2004) acredita que a secularização do pensamento é respondida através da ideologização da religião. Para sobreviver no hostil mundo moderno, caracterizado pela força crescente do poder científico, os escrituralistas (termo utilizado por Geertz para definir aqueles que se voltam às escrituras), não só nos dois países (Indonésia e Marrocos, objetos de pesquisa do autor), mas no movimento em geral, seguiram duas estratégias:

(...) a separação absoluta entre questões religiosas e científicas e a tentativa de mostrar que as escrituras, especialmente o Alcorão, antecipam e estão plenamente de acordo com o espírito e com as descobertas da ciência moderna. A primeira estratégia consiste na negação de qualquer significação metafísica à ciência, na verdade à razão secular em qualquer forma; sua competência está estritamente confinada ao entendimento da natureza, considerada como um tipo de sistema mundano e autocontido. A fé e a razão são separadas por uma espécie de quarentena, para evitar que a primeira seja contaminada, e a segunda, acorrentada. A outra estratégia consiste em interpretar a ciência como não mais que uma explicitação daquilo que já estava implicitamente presente na religião, uma extensão e especificação da perspectiva religiosa, mais do que um modo autônomo de pensamento (Geertz, 2004:112-113). 
No Centro Islâmico de Campinas prevalece a segunda estratégia como mostra o trecho retirado do livro Deus e seus Atributos, de autoria de Sayyed M. M. Lari que me foi presenteado pelo presidente do Centro Islâmico:

Até ao passado recente, o Homem só tinha consciência da sua existência através de seu corpo equilibrado e adequado, mas ignorava os mecanismos misteriosos que regulavam a sua criação. Hoje, o Homem possui informações surpreendentes e detalhadas sobre o interior do seu próprio corpo, e aprendeu que dez milhões de bilhões de células entram na composição dos seus diferentes membros e órgãos. A majestade e a grandeza do Criador tornam-se, assim, ainda mais perceptíveis que no passado. Será lógico sustentar que a crença em Deus é própria das pessoas que não têm conhecimento a respeito da Criação, e que um sábio que está ao corrente da causalidade natural e da evolução em direção à perfeição, e que sabe que uma lei minuciosa rege todas as etapas da existência, deve, pelo contrário, acreditar que a origem das leis naturais não é senão a matéria inanimada? As descobertas e as conclusões científicas poderiam levar a pensar que é possível atribuir todos os poderes do Criador à matéria ignorante e inconsciente? (1995:68-69).

A defesa da busca por conhecimento, não apenas religioso, mas em todas as áreas, faz parte do discurso da comunidade de Campinas, como mostra o trecho retirado de um sermão de sexta-feira:

Temos que nos qualificar em todas as áreas de conhecimento e de atuação profissional. Não podemos ser todos teólogos, ou todos médicos, ou todos engenheiros. Temos que diversificar a nossa participação na sociedade buscando cada vez mais contribuir pelo bem social geral. Assim eram as primeiras gerações de muçulmanos. E assim eles formaram uma grande civilização que durou mais de 700 anos.

A contribuição da civilização islâmica ao desenvolvimento da ciência é lembrada com orgulho em Campinas, assim como as universidades construídas por muçulmanos na península ibérica, onde intelectuais europeus se formaram posteriormente.

Na Liga, também foi dedicado um sermão ao tema do dever da busca pelo conhecimento, "mas o conhecimento verdadeiro, correto". "A diferença entre o sábio e o ignorante", continuou o sheikh, "é a mesma diferença existente entre o profeta e um homem qualquer". Recomendou que procurassem aprender com os sábios, disse que deveriam pro- 
curar os sheikhs para aprender e tomar cuidado com as fontes, já que "nem todo livro ou pessoa traz a informação correta". Em entrevista concedida a mim, depois do gravador ser desligado, um dos fundadores daquela instituição afirmou que Charles Darwin teria que provar que "todos os homens vieram do macaco". Salientou que não acredita nisso e que se não está no Livro (Alcorão), ou está errado, ou o livro foi traduzido errado. "Não está no Alcorão, ou de acordo com este, não concordo nem acredito". O perfeccionismo moral e religioso das lideranças daquela comunidade fez com que lá imperasse a busca pelo isolamento de "uma fé islâmica purificada da contaminação com a vida cotidiana".

Voltando ao debate do fundamentalismo islâmico, no sentido apregoado pela mídia, defendo, assim como Beinin e Stork (1997), o uso do conceito Political Islam. Tal termo é mais adequado para designar os movimentos islamitas desafiadores de regimes existentes e da ordem política que tem se dedicado a servir aos interesses do Ocidente a partir da década de 1970, fundamentalmente.

O 11 de setembro representa um dos mais famosos atos do Political Islam, constituindo um caso valioso de análise do impacto da globalização sobre grupos religiosos muçulmanos ao redor do mundo, uma vez que tanto a ideologia política americana, profundamente orientalista ${ }^{8}$, quanto os argumentos defensivos da Ummah afetaram os muçulmanos. A desconstrução de uma imagem do Islã atrelada à violência e ao terrorismo tem sido, com mais ênfase a partir de então, um problema comum às comunidades muçulmanas ao redor do mundo, constituindo parte efetiva de seu processo de construção identitária. No contexto local, isto pode ser comprovado através da análise dos depoimentos de líderes muçulmanos na mídia, através da literatura nativa criada justamente para este fim, além dos resultados da minha pesquisa de campo em centros islâmicos do Estado de São Paulo. Neste processo, sociedades hospedeiras desempenham um papel extremamente importante, seja no fornecimento de características diacríticas disponíveis, seja no direcionamento da autopercepção deste grupo, uma vez que as construções identitárias espelham o modo como o grupo é percebido pelos outros (Montenegro, 2000). Desta forma, é possível compreender porque os muçulmanos, ao definir sua religião e modo de vida, sempre tocam em determinados assuntos que, "coincidentemente", são aqueles mais destacados pela mídia a respeito deles próprios. 
Além da associação entre religião e terrorismo, pode-se apontar assuntos como poligamia e submissão feminina. Uma mulher respeitada e não oprimida é a imagem que os muçulmanos no Brasil tentam associar ao Islã. Dizem que a mulher, no Islã, é ainda mais respeitada que na cultura e nas sociedades brasileira e ocidental, já que seria valorizada por seu caráter e virtude, e não pela juventude e beleza. Tentam mostrar também que a poligamia é uma exceção, não a regra, e justificada apenas em determinados casos. Alguns deles mostram-se orgulhosos por esta flexibilidade da religião islâmica e a comparam com a imposta monogamia ocidental. A última, segundo eles, apenas acobertaria traições e falta de responsabilidade dos homens com relação aos possíveis frutos de relacionamentos extraconjugais. O Islã, em contraste, garantiria a provisão de apoio emocional e financeiro às demais esposas e filhos. Este tipo de argumento foi ouvido por mim nas duas comunidades pesquisadas.

O simples fato de constituir uma minoria já acarreta algum tipo de sanção, uma vez que toda sociedade impõe modos de ser, pensar e agir que, quando não são seguidos, acarretam sanções que vão do riso à morte física, como nos mostra Durkheim (2004) através de seu conceito de fato social. Estas sanções podem ser mais ou menos amenas dependendo de determinados fatores, como a posição econômica e política que os membros destas minorias ocupam nos países que as abrigam, assim como o tipo de Estado e cultura política presentes em cada um destes países.

O caso brasileiro apresenta diversas peculiaridades no que toca à questão da inserção da minoria muçulmana, em comparação às comunidades muçulmanas presentes na Europa. O sucesso econômico destes imigrantes é uma das principais diferenças, o que não assegura a esta comunidade, porém, condições ideais de prática da sua religião, tampouco, imunidade aos estereótipos propagados pela mídia brasileira, profundamente influenciada pela norte-americana. Como já citado, racismo, xenofobia e estereótipos caracterizam a visão ocidental padrão do Islã em um processo nomeado por Halliday (apud Shadid e Koningsveld, 2002) anti-Muslimism. Há dois tipos de anti-Muslimism, segundo ele: o estratégico e o populista. O primeiro nasceu nos EUA, relacionado e alimentado por assuntos como suprimento de petróleo, bombas nucleares e terrorismo. Surgiu nos anos 1970 como produto da alta de preços do petróleo pela OPEC (Organization of the Petroleum Exporting Countries), da Revolução Iraniana, do conflito relacionado 
à embaixada americana em Teerã, dos atentados ao World Trade Center em 1993, do 11 de setembro e das consequentes análises tendenciosas da mídia. A versão populista é mais comum na Europa e tem ligação com a presença muçulmana nas sociedades ocidentais. Assuntos associados a esta versão são: assimilação, integração, raça, uso do véu e competição por empregos. A globalização tem trazido para o Brasil o anti-Muslimism de tipo estratégico, reforçado em períodos de tensão como o 11 de setembro, fato condizente com a realidade de um país dependente dos EUA e hospedeiro de uma comunidade imigrante muçulmana que não constitui um problema de classe.

Os estereótipos propagados pela mídia são sentidos pela comunidade como um todo, no entanto, a discriminação e o preconceito são vivenciados de forma diferenciada, de acordo com classe, nacionalidade e gênero. Imigrantes do sexo masculino pertencentes às classes média e alta costumam ter contato com o preconceito de forma indireta, através da mídia. Logo que cheguei ao Centro Islâmico em Campinas, por exemplo, fui recepcionada por um senhor egípcio que prontamente me alertou: "Você vai ver, é tudo diferente do que as pessoas dizem. Não somos nada disso, nem extremistas, nem terroristas. É tudo diferente". Outro senhor me perguntou depois de algumas semanas se minha família sabia que eu estava frequentando o Centro. Ao responder afirmativamente, me indagou se não ficavam bravos comigo por estar indo lá. Quando perguntei por que ficariam, respondeu: "Falam muito mal de nós, nos classificam como se fôssemos todos terroristas". "Quem fala?", perguntei. "Os jornais e a TV", me respondeu o empresário.

Mulheres são alvos mais corriqueiros devido ao fato do véu (quando usado) exteriorizar a filiação religiosa. Como as muçulmanas de Campinas usam-no apenas no momento da oração, não constituem um alvo fácil para a discriminação religiosa. Este problema torna-se mais dramático no caso das mulheres convertidas, presentes, em geral, nos grandes centros, como é o caso do bairro do Brás. Ao contrário das árabes, que são vistas pelos brasileiros como "vítimas", as convertidas são vistas como "traidoras do gênero". Como já reportado por Ramos (2003), e confirmado na minha pesquisa de doutorado, a maior parte das ofensas às convertidas é proferida por mulheres, e não homens. Também é comum serem hostilizadas por parentes e amigos que não entendem porque decidiram atrelar-se a uma religião que "pregaria o terrorismo e a submissão das mulheres", algumas chegando a ser expulsas de casa. $\mathrm{O}$ fato de pertencerem a estratos socioeconômicos mais 
baixos também as torna mais vulneráveis ao preconceito dos empregadores. Na Liga da Juventude Islâmica, porém, a rede de solidariedade dos imigrantes pode ser estendida em certas ocasiões para abarcar mulheres convertidas que perderam o emprego devido ao preconceito contra o véu. Não é raro encontrar moças convertidas trabalhando para lojistas árabes.

Quanto às mulheres imigrantes daquela comunidade, pode-se dizer que se dedicam em sua maioria, aos cuidados dos filhos e da casa. Além do mais, não costumam utilizar transporte público, tendo acesso a veículos particulares, o que diminui a probabilidade de sofrer agressões verbais de não muçulmanos. Por fim, vivem no mesmo bairro, o que facilita em certa medida o seguimento dos costumes em um contexto minoritário, além de contarem com uma escola islâmica - na realidade, um colégio católico particular que, mediante pagamento adicional dos imigrantes muçulmanos da região, aceitou oferecer aulas de árabe e religião islâmica para seus descendentes.

Os estereótipos negativos difundidos pela mídia brasileira, profundamente influenciada pela americana, afetam os muçulmanos da Liga da Juventude Islâmica, mas sua situação econômica favorável ameniza, em certa medida, seus efeitos. A globalização, porém, não traz apenas as consequências negativas do anti-Muslimism, ela também permite o estreitamento dos laços da diáspora com o país de origem e demais membros da Ummah, como será demonstrado na próxima seção.

\section{REDES ISLÂMICAS TRANSNACIONAIS}

A Ummah pode ser vista como um ideal religioso ou uma comunidade imaginada, no sentido empregado por Anderson (apud Allievi, 2003), da mesma forma que o estado-nação ou uma comunidade étnica qualquer. Porém, ela existe de fato, reforça Allievi (2003): a solidariedade interna a eventos como os conflitos na Chechênia ou na Bósnia são exemplos comprobatórios, para não mencionar a causa Palestina. A mobilização de recursos, discursos e pessoas mostra a profundidade destes vínculos, completa o autor.

A globalização possibilitou o estreitamento destes vínculos de forma nunca vista anteriormente, contrapondo as teorias que viam neste fenômeno o gerador de uma ocidentalização do resto do mundo, como mostra Stuart Hall: "Pode ser tentador pensar na identidade na era da globalização como estando destinada a acabar num lugar ou noutro: 
ou retornado às suas 'raízes', ou desaparecendo através da assimilação e da homogeneização. Mas, esse pode ser um falso dilema” (2005:86).

Os deslocamentos são mais contraditórios do que parecem, e apesar do Ocidente alimentar em muitos aspectos a globalização, esta pode ser parte de "um lento e desigual, mas continuado descentramento do Ocidente" (Hall, 2005:97). Allievi chama a atenção para a mudança das relações entre centro e periferia causada pela globalização, trazendo à tona um aspecto adicional: a capacidade das periferias contatarem umas às outras, sem a necessidade da intermediação de um centro. No caso do Islã europeu, há relações de centro-periferia representadas pela ligação entre os antigos centros de poder colonizador e as ex-colônias. Por outro lado, os vínculos dos imigrantes muçulmanos na Europa com o "mundo islâmico" produzem conexões entre as periferias... Centros de produção de conhecimento muçulmano, centros simbólicos de oração e o próprio Hajj ${ }^{9}$ criam vínculos efetivos das minorias com o "mundo islâmico". Para finalizar, a evolução tecnológica, com a internet assumindo um papel de destaque, aliada ao barateamento das passagens, diminuiu as distâncias com o país de origem e o resto da Ummah.

O primeiro vínculo transnacional onde se encontram os muçulmanos brasileiros poderia ser apontado como aquele com o país de origem. $\mathrm{O}$ vínculo com o Líbano, país de origem de cerca de $90 \%$ dos muçulmanos no Brasil, desempenha seu papel na reprodução das comunidades muçulmanas no país, do ponto de vista cultural. É comum a visita de parentes e familiares, assim como a ida dos filhos para lá, seja para aprender a língua e os costumes com mais eficiência, seja como estratégia explícita para se arranjar um casamento. Osman (1998) mostra como o casamento com um(a) muçulmano(a) vindo(a) do Brasil pode ser visto como uma grande oportunidade pelos libaneses, devido à prosperidade conquistada pelos imigrantes no país. Por outro lado, também é visto como uma boa oportunidade pelas famílias residentes aqui, já que representaria a preservação da cultura árabe muçulmana no seio da família imigrante.

No caso dos sul-africanos de origem indiana de Campinas, também pude presenciar estratégias semelhantes, porém, sob diferentes justificativas. Enquanto na Liga tentam encontrar um cônjuge adequado para filhos(as) enviando-os(as) para o país de origem com a justificativa de passar um tempo com a família e conhecer melhor a cultura e a 
língua dos pais, em Campinas, os muçulmanos sul-africanos enviam seus filhos(as) para a terra natal com a justificativa de lá realizarem uma pós-graduação. A "pós-graduação" pode render outros frutos, como o casamento com um indivíduo pertencente ao mesmo grupo étnico e religioso. Os diferentes perfis educacionais e ocupacionais das duas comunidades explicam estas posturas diversas para resolver um mesmo problema: encontrar um cônjuge adequado que possibilite a manutenção da identidade étnica e religiosa no contexto minoritário.

O vínculo com o país de origem pode representar também ajuda financeira, no caso da África do Sul. Como já dito, a construção da mesquita de Campinas teve início com uma substanciosa doação da comunidade muçulmana indiana daquele país. O fluxo de capital financeiro no que toca à relação entre Líbano e Brasil caminha pela direção oposta, com um grande número de contribuições dos bem-sucedidos imigrantes à terra natal.

A presença de uma comunidade flutuante formada por muçulmanos de passagem pelo Brasil faz parte do cenário de ambas as mesquitas. Visitas a negócios ou familiares, além dos próprios trabalhos missionários, trazem estas pessoas para o Brasil. A visita de grupos religiosos como os tablighs em Campinas, ou sheikhs e religiosos europeus na Liga faz parte da realidade transnacional destas comunidades e foi presenciada por mim, no período em que realizei minha pesquisa de campo. Por outro lado, lideranças religiosas brasileiras são dirigidas a centros de formação como Al-Azhar no Egito e instituições sauditas. Lideranças como o sheikh da Liga, por sua vez, fazem referências constantes à Ummah e ao dever moral dos muçulmanos no Brasil de ajudar seus irmãos de fé em apuros. Todos os sermões, sem exceção, presenciados por mim no ano de 2006 naquela comunidade, terminavam com um clamor pela proteção "daqueles que lutam em Seu nome, na Palestina, na Chechênia e no Afeganistão".

No aniversário da Intifada, em fins de março de 2006, o sheikh proferiu um discurso sobre o dever do muçulmano brasileiro para com os palestinos, fazendo uma comparação com a solidariedade judaica para com os judeus de Israel ao redor do mundo:

Judeus promovem expansão a cada 10 anos. O que os muçulmanos no Brasil têm a ver com isso? Da mesma forma como os judeus se apoiam e se preocupam com aquele que está longe, os muçulmanos também tem que fazer o mesmo. O muçulmano que não se preocupa com o grupo 
não é nada para os muçulmanos. Por isso, devemos nos preocupar com os palestinos e os iraquianos. Os judeus em todo o mundo dedicam a féria do dia de sábado do McDonald's aos judeus de Israel.

Em outro sermão que versava sobre riqueza, boas ações e merecimento, o sheikh reforçou o dever de ajudar os muçulmanos na Palestina, no Iraque, Afeganistão e Chechênia, e incentivou a destinação de parte do Zakat ${ }^{10}$ para os muçulmanos destes países. Em Campinas, há um apoio moral e político à causa palestina. Ela faz parte do discurso da comunidade, obviamente, mas não com uma frequência tão grande quanto à encontrada na Liga.

No mês de setembro de 2004, durante um almoço dominical da comunidade, houve um discurso proferido em função da visita do candidato do Partido dos Trabalhadores (PT) ao cargo de prefeito de Campinas. Naquela ocasião, falaram sobre o apoio à causa palestina pelo Partido Comunista do Brasil (PCdoB) e PT. Lembraram de Jamil Murad, deputado de origem árabe, filiado ao PCdoB, que sempre apoiou a causa palestina. "Tucanos nunca apoiaram", lembrou o líder da comunidade. Emocionado, afirmou que nunca mais esconderá o que sente e por isso precisava deixar bem claro que os tucanos nunca fizeram nada pela causa árabe palestina, razão de estar apoiando abertamente o PT e o PCdoB naquela eleição. A preocupação com a causa palestina é comum a ambas as comunidades, mas a forma de exercer este apoio pode assumir feições diferenciadas, compatíveis com o perfil socioeconômico desenvolvido por cada um destes grupos no país.

A peregrinação a Meca é mais um fator contribuinte para o caráter transnacional da Ummah. Dever de todo muçulmano "que tem condições financeiras, de saúde e segurança", o Hajj representa uma das maiores celebrações à Ummah, ocasião em que fiéis de todo o mundo, "pessoas de todas as raças e países", oram juntas, "de chineses a africanos". Vínculos transnacionais também são estabelecidos através dos livros e materiais de divulgação da religião produzidos em diversos centros religiosos ao redor do mundo, como Arábia Saudita, Egito e Paquistão, selecionados e distribuídos no Brasil pelo CDIAL e encontrados tanto em Campinas quanto no Brás.

Para finalizar, cito o estreitamento dos vínculos a partir da internet, não apenas com os países de origem e as sociedades majoritariamente muçulmanas, mas também com as minorias no Ocidente como mostra o trecho extraído de um discurso da Liga: "Nossos irmãos muçulma- 
nos nos EUA disseram em um (web) site que este ano será o ano do Islã. Precisamos fazer de 2006 o ano em que levaremos informação correta para os outros".

\section{A NEGOCIAÇÃO DAS IDENTIDADES NO INTERIOR DAS COMUNIDADES MUÇULMANAS BRASILEIRAS}

A construção de identidades muçulmanas ocorre ainda em outro nível: no interior das comunidades muçulmanas brasileiras. As negociações internas a essas comunidades constituem um importante fator de análise do processo de definição do que é ser muçulmano ou muçulmana no Brasil. Aspectos étnicos, nacionais e de gênero interferem neste processo de forma bastante visível.

A recente presença de brasileiros nas mesquitas, que até então eram compostas fundamentalmente por um grupo étnico que se vê e é visto como árabe, tem sido sentida por este último como uma ameaça à tentativa de preservação cultural do grupo. Conflitos ideológicos, tensões e negociações têm feito parte da realidade de várias destas instituições a partir de então, como já reportado por Montenegro (2000), Marques (2000) e Ramos (2003).

O Islã nasceu entre os árabes, e no Brasil é seguido fundamentalmente por imigrantes e descendentes que se identificam com esta etnia, atrelando sua origem étnica à tradição da religião. Neste contexto, "a identidade redesenhada e aceita através do comprometimento ao Islã difere dos nascidos muçulmanos árabes; o brasileiro será muçulmano, comprometido com a religião, porém será sempre convertido" (Marques, 2001:162). O contato dos convertidos com a "comunidade árabe" não é contínuo, nem íntimo, sendo permeado por conflitos, o que também pode provocar uma assimilação deficitária do ethos religioso (Ramos, 2003:186).

Os brasileiros convertidos reconhecem sua "subordinação" atual a uma estrutura religiosa marcada por aspectos culturais árabes bastante manifestos, mas não perdem as esperanças de ver a religião islâmica assumir uma face mais brasileira no país com o aumento do número de conversões. Atacam os árabes e seus descendentes defendendo uma escolha identitária baseada na "islamização", em contraposição ao que chamam de "arabismo", uma espécie de viés que deturparia a verdadeira religião islâmica, tingindo-a com traços culturais que os desfavorecem. 
A teoria dos campos de Bourdieu (apud Ortiz, 1994) nos permite compreender com mais propriedade o antiarabismo por parte dos detentores de menor capital social dentro do campo religioso islâmico. Se pensarmos no capital social dentro deste campo como a herança da tradição religiosa que remonta à fundação da religião, teremos os árabes como dominantes e os convertidos, sejam eles, brasileiros, indianos ou qualquer muçulmano não árabe, como dominados ${ }^{11}$.

As ações dentro do campo não são neutras e os agentes procuram sempre maximizar seus "lucros". Dessa forma, suas ações, orientadas em função de sua posição no grupo, pressupõem sempre uma gama de interesses. Ao dividir o campo social em dominantes e dominados, Bourdieu torna necessário retomar a distinção weberiana entre ortodoxia e heterodoxia.

As práticas dos atores pertencentes ao polo dominante atêm-se à ortodoxia, já que pretendem conservar intocado o capital social que conseguiram acumular. Neste aspecto, a valorização da tradição árabe desempenha seu papel de forma marcante. Por outro lado, os dominados apegam-se às práticas heterodoxas que visam desacreditar os detentores de um capital considerado legítimo. Procuram manifestar seu inconformismo através de estratégias de subversão, confrontando-se de maneira permanente com a ortodoxia. Tais estratégias, porém, não contestam fundamentalmente os princípios que regem a estruturação do campo. Os convertidos clamam uma superioridade moral sobre os árabes, porém, a partir de um argumento retirado da própria religião islâmica, segundo o qual a fé seria o único diferencial aceitável entre os homens.

A reação de antiarabismo apresentada pelos convertidos brasileiros na Liga pôde ser vista de forma semelhante entre os imigrantes de origem indiana em Campinas. Ouvi de diversos imigrantes e descendentes sul-africanos de origem indiana o argumento de que os árabes fundaram a religião, mas os indianos são os mais fiéis seguidores do Islã. A ideia da superioridade dos indianos perante aos árabes no que toca ao seguimento correto da religião é um argumento que faz parte do "senso comum" dos indianos muçulmanos mundo afora. Pode-se pensar nos indianos muçulmanos como convertidos, partindo-se do estamento de Naipaul, segundo o qual "todo muçulmano de origem não árabe é um convertido", devido às desvantagens simbólicas e culturais advindas da ausência de um background árabe. Mas ainda que haja dispu- 
tas entre diferentes grupos étnico-nacionais abarcados pelo Islã (árabes, brasileiros, indianos etc.), quando este é atacado, é defendido por todos os outros, garantindo a existência do campo.

Além dos conflitos entre árabes e convertidos de ascendência não árabe (brasileiros ou indianos) no interior das comunidades muçulmanas, foi possível constatar disputas entre homens e mulheres pela definição de como devem agir e pensar muçulmanos e muçulmanas no Brasil. A questão da relação entre gêneros nas sociedades e comunidades muçulmanas é extremamente complexa e profundamente marcada por batalhas ideológicas e políticas. Uma análise da construção da identidade muçulmana feminina no Brasil, país dependente dos EUA e detentor da maior comunidade muçulmana da América Latina, precisa estar atenta ao que se encontra em jogo neste contexto. O Islã vem sendo alvo de um processo de "demonização" de toda uma religião e seu conjunto de fiéis, onde uma das principais estratégias empregadas visando a sua deslegitimação refere-se justamente à imposição do rótulo de "opressor de mulheres".

As mulheres muçulmanas no país definem sua identidade em resposta à imagem difundida pela mídia brasileira, extremamente influenciada pela mídia norte-americana, ao mesmo tempo em que enfrentam o patriarcalismo ${ }^{12}$ no interior das comunidades étnico-religiosas. A construção da identidade muçulmana destas mulheres é, portanto, realizada em resposta à mídia e em negociação com a parcela masculina de sua própria comunidade religiosa, defendendo perante esta o direito a um maior poder e respeito a partir da própria religião e suas leis ou, ainda, através de uma relativização da tradição. Por exemplo, a líder do departamento feminino da Liga reafirmou a importância do estudo para as mulheres apoiando-se no exemplo do profeta Muhammad: "se não fosse necessário que as mulheres aprendessem, o profeta não teria ensinado suas esposas". Em outra ocasião, contrapôs-se ao argumento de um sheikh estrangeiro que visitava a comunidade, quando este afirmou que a oração feminina tem mais valor quando feita em casa, em uma tentativa de evitar a ida das mulheres até a mesquita. A jovem rebateu o argumento relativizando esta crença ao alegar que no Brasil é vital que as mulheres frequentem a mesquita "como forma de conhecimento", já que os muçulmanos representam uma minoria religiosa e, portanto, não há tantas possibilidades de socialização na sua cultura.

O discurso oficial das jovens lideranças masculinas da Liga, no que se refere à mulher muçulmana e à relação entre gêneros, é marcado pelo 
rigor e perfeccionismo moral e religioso, com poucas e pequenas concessões ao contexto local. Em Campinas, o discurso das lideranças masculinas já é mais flexível. Enquanto na Liga os líderes alegam que a mulher tem o direito de estudar e trabalhar, desde que isso não atrapalhe suas obrigações para com a casa e a família, em Campinas, os líderes chamam atenção para o dever de homens e mulheres buscarem o conhecimento. O diploma de ensino superior é um objetivo comum para rapazes e moças daquela comunidade. Em Campinas, as mulheres casam-se mais tarde e recebem um investimento maior em sua educação em comparação ao que acontece na Liga. Porém, o papel de provedor da família ainda é visto por elas como inerentemente masculino, mesmo quando poderiam desempenhar esta tarefa como mulheres educadas e empregadas que são.

Por fim, convém citar a questão do hijab. Enquanto seu uso é fortemente recomendado pelas lideranças da Liga, para demonstrar modéstia e preservar a castidade, em Campinas ele é descrito como "meio de preservação da identidade muçulmana em contextos de perseguição política", "forma de se adaptar ao clima", no caso da Arábia Saudita, ou ainda, "roupa de oração", isto é, vestimenta a ser utilizada para cobrir o corpo e o cabelo no momento da oração. Os discursos das lideranças destas comunidades são bastante diferenciados. Primeiro, pela não obrigatoriedade do véu em Campinas e o esforço de enfatizar seu uso na Liga. Segundo, pelo "perfeccionismo religioso e moral" da Liga em contraposição aos argumentos baseados em critérios culturais, políticos e até mesmo climáticos em Campinas.

A prática cotidiana, porém, no que toca à vestimenta islâmica e aos papéis sociais atribuídos às mulheres, mostra que, apesar do rigor eventual do discurso das lideranças da Liga, há um processo de individualização da religiosidade muçulmana, onde os fiéis negociam de forma relativamente autônoma com a sociedade hospedeira a prática de certos aspectos comportamentais. Por fim, é importante salientar que grau de instrução, grupo étnico, faixa etária e classe social desempenham seu papel neste processo de construção identitária trazendo nuances que podem aproximar ou afastar estas mulheres no que toca a sua concepção de como deve pensar e agir uma mulher muçulmana no Brasil.

\section{CONSIDERAÇÕES FINAIS}

Ao dedicar-me ao estudo da construção de identidades muçulmanas no Brasil, tive como intuito demonstrar, desde o princípio, a diversida- 
de de valores, crenças e concepções abrangidas pelo termo "muçulmano". O Islã, apesar de apresentado pela mídia e academia orientalistas como um bloco monolítico, constitui uma religião tão diversa e complexa quanto o Cristianismo. Considero os casos explorados neste artigo, a Liga da Juventude Islâmica e o Centro Islâmico de Campinas, exemplos privilegiados de análise por construírem identidades muçulmanas tão diversas em resposta ao contexto hospedeiro brasileiro. Vejo seus diferentes perfis étnicos, ocupacionais, de liderança e distribuição espacial como a chave para se compreender esta diversidade de interpretações sobre o que é ser muçulmano(a) no Brasil de hoje.

Apesar da doutrina islâmica não pregar a discriminação de raça e/ou etnia, não se pode negar a vantagem real que a origem árabe confere a um(a) muçulmano(a). Como já mencionado, este grupo étnico possui um vínculo com a tradição de fundação da religião que um muçulmano sem ascendência árabe jamais terá. A visão do árabe como o idioma da revelação divina traz dificuldades práticas bastante expressivas para o convertido, uma vez que a realização das orações e a leitura do Alcorão devem ser feitas nesta língua. A reação ao arabismo permeia o discurso dos convertidos, chegando a promover, inclusive, o desligamento de alguns indivíduos de comunidades religiosas fundadas por árabes, visando a criação de um lócus para a vivência de uma religiosidade mais "islamizada" e menos sujeita a "influências culturais"13.

Quanto ao impacto do tipo de ocupação sobre a construção de identidades muçulmanas nas duas comunidades, convém dizer que ele se dá não tanto devido à influência do ethos desenvolvido em cada ambiente laboral ${ }^{14}$, mas, principalmente, devido ao grau de contato com a sociedade hospedeira possibilitado por cada tipo de atividade econômica. Segundo Roald (2001), as interpretações de questões sociais a partir de fontes islâmicas são claramente afetadas pela interação com as estruturas sociais ao redor, atentando para alguns fatores como tempo de permanência no país hospedeiro, grau de contato com a sociedade mais ampla, classe social, modelos educacionais e, por fim, disposição pessoal.

A questão do contato é exemplificada por Roald através do caso dos subúrbios suecos habitados, em sua maioria, por muçulmanos. Nestes locais, atitudes tradicionalistas referentes às mulheres e à vida em família, por exemplo, são reproduzidas a despeito do tempo de permanência no país e do novo contexto cultural. A maior rigidez e "perfec- 
cionismo moral" (usando as palavras de Geertz) encontrados na comunidade da Liga da Juventude Islâmica (não apenas no que toca à questão de gênero) podem ser pensados a partir das variáveis tempo de permanência e contato com a sociedade mais ampla, acrescidas da questão das lideranças.

A Liga é uma comunidade formada por imigrantes recentes, beirando à homogeneidade étnica, concentrados em um único bairro e apresentando um contato superficial com os brasileiros através do comércio. Já o Centro Islâmico de Campinas tem seus membros vivendo dispersos pela cidade, trabalhando de forma relativamente independente através do exercício de atividades educacionais, ocupação que requer um longo e intenso contato com os brasileiros. A maior flexibilidade do discurso dos muçulmanos campineiros explica-se, em parte, não exatamente pelo seu maior capital cultural, mas, principalmente, pelo maior contato com a sociedade mais ampla e seus valores de influência ocidental, como a igualdade entre os gêneros.

A isto, alia-se o fato da mesquita de Campinas ter ficado um bom tempo sem contar com um sheikh ${ }^{15}$ estrangeiro, o que ajudou a surgir, naquela comunidade, uma visão religiosa mais flexível e menos conservadora por parte das lideranças. Durante minha pesquisa de campo, percebi que o indivíduo mais influente da comunidade de Campinas era um professor universitário de grande prestígio acadêmico, porém sem formação teológica formal, um perfil de liderança bastante diferente do encontrado na Liga, comunidade tradicionalmente guiada por sheikhs estrangeiros formados em grandes centros teológicos como Al-Azhar, no Egito, além da própria Arábia Saudita. Concluo este artigo, portanto, chamando a atenção para o impacto que a formação destes líderes pode exercer sobre a seleção e interpretação das fontes islâmicas, processo que, ao fim, afeta a construção de identidades muçulmanas no Brasil.

(Recebido para publicação em junho de 2009) (Reapresentado em junho de 2012 e em outubro de 2014) (Aprovado para publicação em outubro de 2014) 


\section{NOTAS}

1. Agrego a estes fatores informações sobre as lideranças de cada comunidade, uma vez que elas também contribuem para a conformação dos produtos identitários em questão.

2. Conceito nativo que designa a "comunidade islâmica mundial", isto é, o conjunto de indivíduos que se consideram muçulmanos ao redor do mundo.

3. É importante salientar que as esferas internacionais e locais não se encontram dissociadas de forma alguma, assim como questões de classe, gênero, etnia... Fiz tais divisões apenas para facilitar a apresentação dos dados.

4. Até o final da Primeira Guerra Mundial, o termo Grande Síria englobava o Líbano em suas fronteiras.

5. Outros grupos de imigrantes também chegaram ao Brasil sem capital, mas não se tornaram mascates, entretanto.

6. Aula ministrada em maio de 2006.

7. Nome dado por Halliday (apud Shadid e Koningsveld, 2002:176) ao processo em que racismo, xenofobia e estereótipos caracterizam a visão ocidental do Islã.

8. Utilizo tal termo baseando-me no conceito de "Orientalismo" formulado por Edward Said (1990) para definir todo um modo de pensar e produzir conhecimento que criou a imagem de um Oriente dependente e incapaz de modo a legitimar a exploração destes países pelos impérios francês e inglês, numa primeira fase, e pelos americanos, ao fim.

9. Peregrinação a Meca.

10. O Zakat constitui a doação de $2,5 \%$ dos lucros anuais dos muçulmanos aos mais pobres. Representa um dos cinco pilares da religião islâmica, sendo os demais: 1) a shahada, declaração de que só existe um Deus e Muhammad é seu mensageiro; 2) as cinco orações diárias; 3) o jejum durante o mês do Ramadã, significando a abstenção de comida, bebida e relações sexuais, do nascer ao pôr do sol; e por fim, 4) o Hajj, a peregrinação a Meca, obrigatória a todo muçulmano e muçulmana com condições físicas e financeiras.

11. Utilizo a visão de Bourdieu da polaridade entre dominantes e dominados na análise das disputas realizadas entre diferentes grupos étnicos pela construção da "identidade muçulmana" devido à vantagem cultural dos árabes oriunda de seu vínculo com a tradição de fundação da religião e a importância religiosa da língua árabe, seja como idioma da revelação divina, seja como a língua usada obrigatoriamente nas orações. A isso, soma-se a questão da territorialidade, representada pela presença dos lugares sacros na Arábia Saudita. Todos estes fatores conferem uma vantagem real aos árabes em relação a qualquer muçulmano de origem não árabe. Desta forma, a polaridade entre dominantes e dominados, proposta por Bourdieu, apresenta-se com mais veemência neste campo. A própria ênfase dos muçulmanos brasileiros e indianos, por exemplo, na ideia de que eles são "os mais fiéis seguidores do Islã", mostra a reação a esta desvantagem cultural em relação aos árabes. No caso das disputas entre gêneros, porém, é possível pensar no poder como algo menos polarizado. Desta forma, utilizaria a concepção de poder de Foucault (1997) para analisar a disputa entre homens e mulheres pela construção da identidade muçulmana. 


\section{Cristina Maria de Castro}

12. Durante a condução da minha pesquisa de campo, ouvi de convertidas brasileiras e indianas o argumento de que a dominação masculina seria uma consequência cultural árabe. Da líder do departamento feminino da Liga, uma imigrante libanesa de segunda geração, ouvi que os abusos a que são sujeitas as mulheres muçulmanas são oriundos da forma equivocada como a religião vem sendo praticada, além da educação oriental a que são submetidas estas moças, educação que pregaria a submissão e a dependência femininas. Para mais detalhes sobre a visão das muçulmanas no Brasil a respeito da dominação feminina no Islã, consultar Castro (2008).

13. Pode-se apontar como exemplos a sala de orações criada por convertidos brasileiros no centro de Belo Horizonte e a Comunidade Bilal al Habashi, fundada na cidade de São Paulo por muçulmanos africanos e brasileiros ligados ao movimento negro. Segundo informantes, alguns convertidos deixaram a Liga para integrar esta comunidade.

14. Apesar deste não ser desprezível de forma alguma. A ausência de críticas ao consumismo na Liga da Juventude Islâmica é coerente com o perfil de seus membros: comerciantes de roupas. A valorização, em Campinas, do conhecimento em todas as suas formas, não apenas a teológica, também é compatível com o perfil de uma comunidade formada em grande medida por pesquisadores e educadores de diversas áreas, liderados naquele momento por um acadêmico sem formação teológica tradicional.

15. Na ausência de sheikhs com uma formação religiosa formal, obtida em centros de educação religiosa oficiais, escolhe-se como líder(es), o(s) indivíduo(s) que apresen$\mathrm{ta}(\mathrm{m})$ maior conhecimento da religião, além de reputação ilibada. 


\section{REFERÊNCIAS BIBLIOGRÁFICAS}

ALLIEVI, Stefano. (2003), "Islam in the Public Space: Social Networks, Media and NeoCommunities", in S. Allievi e J. Nielsen (orgs.), Muslim Networks and Transnational Communities in and Across Europe. Leiden, Brill, pp. 1-27.

ARMSTRONG, Karen. (2001), Em Nome de Deus. São Paulo, Companhia das Letras.

BEININ, Joel e STORK, Joe. (1997), “On the Modernity, Historical Specificity and International Context of Political Islam", in J. Beinin e J. Stork (orgs.), Political Islam: Essays from Middle East Report. London, I. B. Tauris.

BRANDÃO, Carlos Rodrigues. (1988), "Ser Católico: Dimensões Brasileiras um Estudo sobre a Atribuição através da Religião", in V. Sachs (org.), Brasile EUA: Religião e Identidade Nacional. Rio de Janeiro, Graal, pp. 27-57.

CASTRO, Cristina Maria de. (2007), A Construção de Identidades Muçulmanas no Brasil: Um Estudo das Comunidades Sunitas da Cidade de Campinas e do Bairro Paulistano do Brás. Tese de Doutorado, UFSCar, São Carlos, São Paulo.

(2008), "Muçulmanas no Brasil: Reflexões sobre a Relação entre Religião e Dominação de Gênero". Mandrágora, no 14, pp. 80-96.

CHAGAS, Gisele Fonseca. (2006), Identidade, Conhecimento e Poder na Comunidade Muçulmana do Rio de Janeiro. Dissertação de Mestrado, UFF, Niterói, Rio de Janeiro.

DURKHEIM, Émile. (2004), As Regras do Método Sociológico. São Paulo, Martins Fontes.

ESPINOLA, Cláudia Voigt. (2005), O Véu que (Des)cobre: Etnografia da Comunidade Árabe Muçulmana em Florianópolis. Tese de Doutorado, UFSC, Florianópolis.

FERREIRA, Francirosy C. Barbosa. (2001), Imagem Oculta: Reflexões sobre a Relação entre os Muçulmanos e a Imagem Fotográfica. Dissertação de Mestrado, USP, São Paulo.

(2007), Entre Arabescos, Luas e Tâmaras: Performances Islâmicas em São Paulo. Tese de Doutorado, USP, São Paulo.

FOUCAULT, Michel. (1997), Microfísica do Poder (11 ${ }^{\mathrm{a}}$ ed.). Rio de Janeiro, Graal.

GATTAZ, André Castanheira. (2001), História Oral da Imigração Libanesa para o Brasil: 1880 a 2000. Tese de Doutorado, USP, São Paulo.

GEERTZ, Clifford. (2004), Observando o Islã. Rio de Janeiro, Jorge Zahar.

GUILHON, Gisele. (2006), A Arte Secreta dos Dervixes Giradores: Um Estudo Etnocenológico do Sama Mevlevi. Tese de Doutorado, UFBA, Salvador.

HALL, Stuart. (2005), A Identidade Cultural na Pós-Modernidade (10a ed.). Rio de Janeiro, DP\&A Editora.

HAMID, Sônia Cristina. (2007), Entre a Guerra e o Gênero: Memória e Identidade de Mulheres Palestinas em Brasília. Dissertação de Mestrado, UnB, Brasília.

LARI, Sayyed M. M. (1995), Deus e seus Atributos. Loures, Al Furqán.

MARIZ, Cecília e PERES, Vitória. (2006), “Conversion to Islam in Contemporary Brazil”. Exchbage, vol. 35, no 1, pp. 102-115. 


\section{Cristina Maria de Castro}

MARQUES, Vera Lúcia Maia. (2000), Conversão ao Islam: O Olhar Brasileiro, a Construção de Novas Identidades e o Retorno à Tradição. Dissertação de Mestrado, PUC, São Paulo.

MONTENEGRO, Ślvia Maria. (2000), Dilemas Identitários do Islam no Brasil: A Comunidade Muçulmana Sunita do Rio de Janeiro. Tese de Doutorado, UFRJ, Rio de Janeiro.

ORTIZ, Renato. (1994), "Introdução”, in Pierre Bourdieu/Sociologia (2aed.). Tradução Paula Montero. São Paulo, Ática (Coleção Grandes Cientistas Sociais).

OSMAN, Samira. (1998), Caminhos da Imigração Árabe em São Paulo: História Oral da Vida Familiar. Dissertação de Mestrado, USP, São Paulo.

. (2007), Entre o Líbano e o Brasil: Dinâmica Migratória e História Oral de Vida. Tese de Doutorado, USP, São Paulo.

PINTO, Paulo Hilu. (2012), “Ritual, Etnicidade e Identidades Religiosas em Comunidades Muçulmanas no Brasil”, ,in J. B. B. Pereira (org.), Religiosidade no Brasil. São Paulo, Edusp.

RAMOS, Vlademir Lúcio. (2003), Conversão ao Islã: Uma Análise Sociológica da Assimilação do Ethos Religioso na Sociedade Muçulmana Sunita em São Bernardo do Campo na Região do Grande ABC. Dissertação de Mestrado, UMESP, São Bernardo do Campo, São Paulo.

REIS, João José. (2003), Rebelião Escrava no Brasil: A História do Levante dos Malês (1835). São Paulo, Companhia das Letras.

ROALD, Anne Sofie. (2001), Women in Islam: The Western Experience. London/New York, Routledge.

SAID, Edward W. (1990), Orientalismo: O Oriente como Invenção do Ocidente. São Paulo, Companhia das Letras.

SHADID, Wasif e KONINGSVELD, Sjoerd van. (2002), Intercultural Relations and Religious Authorities: Muslims in the European Union. Leuven, Ed. Peeters.

TRUZZI, Oswaldo M. S. (1997), Patrícios - Sírios e Libaneses em São Paulo. Tese de Doutorado, Unicamp.

WANIEZ, Philippe e BRUSTLEIN, Violette. (2001), “Os Muçulmanos no Brasil: Elementos para uma Geografia Social”. Revista Alceu, vol. 1, no 2, pp. 155-180. 


\section{RESUMO}

A Construção de Identidades Muçulmanas: Um Enfoque Comparativo entre Duas Comunidades Paulistas

Este artigo analisa a construção de identidades muçulmanas no Brasil. Procura-se mostrar como se dá este processo frente ao campo religioso brasileiro, às pressões advindas da globalização e às tensões internas entre gêneros e entre imigrantes de origem árabe e convertidos. Através da aplicação da técnica de observação participante junto à Liga da Juventude Islâmica e ao Centro Islâmico de Campinas, o texto permite observar uma multiplicidade de crenças e práticas islâmicas desenvolvidas em solo brasileiro.

Palavras-chave: sociologia da Religião; Islã; identidade; imigração; muçulmanos; Brasil

\section{ABSTRACT}

The Construction of Muslim Identities: A Comparative Perspective between Two São Paulo Communities

This article analyzes the construction of Muslim identities in Brazil. It seeks to show how this process fundamentally unfurls amidst the field of religions in Brazil, the pressures created by globalization, and the internal tension between genders and among converted Arab immigrants. Through the participant-observation technique at the Islam Youth League and the Campinas Islamic Center it was possible to observe the multiplicity of Islamic beliefs and practices being carried out in Brazilian soil.

Keywords: sociology of religion; Islam; identity; immigration; Muslims; Brazil 


\section{Cristina Maria de Castro}

\section{RÉSUMÉ}

La Construction des Identités Musulmanes: Une Approche Comparative de Deux Communautés de São Paulo

Cet article analyse la construction des identités musulmanes au Brésil. L'objectif é de montrer comment fonctionne ce processus, fondamentalement face au domaine religieux brésilien, aux pressions exercées par la mondialisation et aux tensions internes entre genres et entre immigrants d'origine arabe et convertis. A partir de l'application de la technique de l'observation participante auprès de la Ligue de la Jeunesse Islamique et du Centre Islamique de Campinas, une multitude de croyances et de pratiques islamiques développés dans le sol brésilien purent être observées.

Mots-clés: sociologie de la religion; Islam; identité; immigration; musulmans; Brésil

\section{RESUMEN}

La Construcción de Identidades Musulmanas: Un Enfoque Comparativo entre Dos Comunidades de São Paulo

Este artículo analiza la construcción de identidades musulmanas en Brasil. Se busca demostrar cómo se produce este proceso frente al campo religioso brasileño y las presiones ejercidas por las dinámicas globalizantes, bien como ante las tensiones internas entre géneros y entre inmigrantes de origen árabe y convertidos. A través de la aplicación de la técnica de observación participante junto a la Liga de la Juventud Islámica y al Centro Islámico de Campinas, el texto pone de manifiesto y discute una multiplicidad de creencias y prácticas islámicas desarrolladas en solo brasileño.

Palabras clave: sociología de la religión; Islam; identidad; inmigración; musulmanes; Brasil 